Board role performance and faultlines in family firms: The moderating role of formal board evaluation

Peer-reviewed author version

VANDEBEEK, Alana; VOORDECKERS, Wim; LAMBRECHTS, Frank \& HUYBRECHTS, Jolien (2016) Board role performance and faultlines in family firms: The moderating role of formal board evaluation. In: JOURNAL OF FAMILY BUSINESS STRATEGY, 7(4), p. 249-259.

DOI: $10.1016 / \mathrm{j} . j \mathrm{fbs} .2016 .10 .002$

Handle: http://hdl.handle.net/1942/23251 


\author{
Alana Vandebeek \\ Hasselt University \\ Research Center for Entrepreneurship and Family Firms (RCEF) \\ Martelarenlaan 42 \\ 3500 Hasselt (Belgium) \\ E-mail: alana.vandebeek@uhasselt.be \\ Wim Voordeckers \\ Hasselt University \\ Research Center for Entrepreneurship and Family Firms (RCEF) \\ Martelarenlaan 42 \\ 3500 Hasselt (Belgium) \\ E-mail: wim.voordeckers@uhasselt.be \\ Corresponding author \\ Frank Lambrechts \\ Research Center for Entrepreneurship and Family Firms (RCEF) \\ Hasselt University \\ Martelarenlaan 42 \\ 3500 Hasselt (Belgium) \\ E-mail: frank.lambrechts@uhasselt.be \\ Jolien Huybrechts \\ Maastricht University \\ Tongersestraat 53 \\ 6122LM Maastricht (The Netherlands) \\ E-mail: j.huybrechts@maastrichtuniversity.nl
}




\title{
Board role performance and faultlines in family firms: The moderating role of formal board evaluation
}

\begin{abstract}
Recent research on the actual behaviour of boards suggests that more attention should be given to group dynamics in boards of directors. Therefore, we investigate if faultlines are detrimental to the role performance of boards of directors in family firms. In contrast to previous studies that only focus on one attribute, we use a more encompassing measure of faultlines, which is based on three attributes simultaneously (family-membership, type of directorship, and gender). Furthermore, we investigate the moderating role of formal board evaluation. Findings suggest a negative relationship between faultlines and both board control and service role performance. Interestingly, our study indicates that in boards that use formal evaluations, the negative effect of faultlines on control role performance is reversed. We discuss implications for faultline theory and research on boards of directors.
\end{abstract}

\section{KEYWORDS}

Board composition, Board processes, Faultlines, Board evaluation, Family firms 


\section{Introduction}

A growing body of literature focuses on identifying the underlying mechanisms that explain differences in board role performance among family firms and calls for more research on the group dynamics that are present in these boards (Bammens, Voordeckers, \& Van Gils, 2011; Collin \& Ahlberg, 2012; Zattoni, Gnan, \& Huse, 2015). In the specific setting of family firms, where the board can be composed of both family members and outsiders, the roles and behaviours of family versus other board members may be different due to possibly diverging viewpoints and interests (Bammens et al., 2011). For instance, Anderson and Reeb (2004) suggested that independent directors play a role in alleviating conflicts between shareholder groups and mitigating the family's power, which presented an opportunity for performance premiums for family-owned firms with higher levels of board independence. Moreover, families may nominate those outside directors to heighten the task-relevant skills of their board (Anderson \& Reeb, 2004; Bammens et al., 2011; Zattoni et al., 2015). While this greater diversity in the boardroom seems beneficial for performance, owing to the increased availability of functional knowledge and skills, there are downsides to be considered as well.

One of these potential downsides, is the emergence of group faultlines, "hypothetical dividing lines that may split a group into subgroups based on one or more attributes" (Lau \& Murnighan, 1998, p. 328). These faultlines may be grounded in demographic attributes, such as gender, as well as nondemographic characteristics, such as certain family attributes. The concept of faultlines is based on the alignment of several diversity attributes of individuals, and faultlines become stronger as more characteristics align themselves in the same way (Lau \& Murnighan, 1998). For example, in a board composed of two female family executive directors and two male outside directors, based on the alignment of three attributes (i.e., gender, family membership and type of directorship) two homogenous subgroups are likely formed, creating 
a strong faultline. Family members are expected to create a highly committed "in-group" (Uhlaner, Wright, \& Huse, 2007), as they may prefer working with other members of the family and may trust them more than outsiders. Subgroup formation in turn could have a detrimental effect on board cohesiveness, which is linked to board role performance (Forbes \& Milliken, 1999).

To our knowledge, only two studies have focused on faultlines in the context of family firms. Firstly, Minichilli, Corbetta, and MacMillan (2010) argue that the proportion of family members in the top management team (TMT) will lead to faultlines among factions of family and nonfamily top executives. They found a U-shaped relationship between the ratio of family members in the top management team and firm financial performance, with a faultline occurring when there is a "balanced" representation of family and nonfamily members in the TMT. Another study, conducted by Basco and Voordeckers (2015), expected faultlines in the boards of private family firms between outside and inside directors, and found an inverted U-shaped pattern in the relationship between the outside director ratio and firm performance.

However, in spite of the important contributions of their findings, these studies link faultlines to firm performance. Governance studies have been focusing on finding a relationship between board demographics and firm outcomes (Daily, Dalton, \& Cannella Jr, 2003; Johnson, Ellstrand, \& Daily, 1996). However, contrasting findings and insignificant results (Dalton, Daily, Ellstrand, \& Johnson, 1998; Pettigrew, 1992) have resulted in an ongoing search for the mechanisms that link input variables, such as board composition, to output variables, such as firm financial performance (Forbes \& Milliken, 1999; Gabrielsson \& Huse, 2005; van Ees, Gabrielsson, \& Huse, 2009; Westphal \& Zajac, 2013). To gain more understanding of the intervening processes through which board demographics influence firm performance, researchers must explore the effect of board demographics on board functioning and role 
performance. Moreover, our knowledge of the influence of complex group dynamics on board role performance in general, and especially in the specific setting of family firms, remains limited. We attempt to fill this gap in the literature by addressing the following research question: what is the effect of group faultlines on board role performance in family firms?

Previous studies either use the family ratio or outsider ratio to explain the phenomenon of faultlines in the specific context of family firms. In order to really capture the effect of faultlines, as first conceptualized by Lau and Murnighan (1998), a more precise way of measuring and identifying faultlines and subgroups in family firms is recommended. Therefore, we use the method of Shaw (2004), which assesses the extent to which categorical attributes are aligned within subgroups and deviate between subgroups. This provides us with a more encompassing measure of faultlines, since this method incorporates multiple attributes. More specifically, we will take the attributes "family membership" (i.e., part of the family or not), "type of directorship" (i.e., executive, nonexecutive or other) and "gender" into account.

Furthermore, there is still no general agreement about the effect of faultlines and resulting subgroups on group performance, as there are also scholars who argue that faultlines are not necessarily detrimental. For example, Bezrukova and Uparna (2009) claim that stronger faultlines can stimulate a culture shift from a desired to an actual culture of creativity in a team, which in turn might influence the team's creativity and performance. These contradictory results may be the result of the highly contextual nature of the effect of faultlines (Meyer, Glenz, Antino, Rico, \& González-Romá, 2014). That is, there may be some contexts where the faultline effects are exacerbated, or potentially mitigated.

An important attribute of the board's context, which has been mainly overlooked in previous board research, is the formal evaluation of the board of directors. Indeed, board evaluations can serve as an opportunity to discuss potential faultline issues which could help 
counteract the detrimental effects of faultlines. In addition, board evaluation may have a positive effect on the identification of the members with the board as a whole, thereby stimulating board cohesiveness, which in turn has the potential to indirectly influence board role performance (Forbes \& Milliken, 1999; Zona, 2015). As Edmondson, Dillon, and Roloff (2007) stated, low identification with the group as a whole, or low "collective team identification," leads to difficulties when trying to capture the benefits of diversity for learning, which in turn is an important component of team effectiveness (Edmondson et al., 2007). Building on previous studies that assert the potential detrimental effect of faultlines on grouplevel outcomes (Bezrukova, Jehn, Zanutto, \& Thatcher, 2009; Choi \& Sy, 2010; Rico, Molleman, Sanchez-Manzanares, \& Vegt, 2007; Thatcher, Jehn, \& Zanutto, 2003), our study aims at unravelling the implications of faultlines on board role performance in boards that use formal evaluations as well as in those that do not.

We provide several contributions to the field. First, we examine the effect of faultlines in the specific setting of family firms, as family characteristics may have important implications for the presence of faultlines (Bammens et al., 2011; Collin \& Ahlberg, 2012; Zattoni et al., 2015). Second, by adopting principles from the organizational behaviour literature, this study contributes to the emergent dialogue on group dynamics in boards of directors. Our study responds to calls in the corporate governance literature to open up the "black box" of corporate boards (Huse, Hoskisson, Zattoni, \& Viganò, 2011), as we investigate the faultline effect on the board level and gain a better understanding of the antecedents of board role performance in family firms. Third, we contribute by empirically testing the relationship between faultlines and board role performance, using a comprehensive method of calculating faultlines. By adding the variable "family membership" as an additional social category attribute, this study adds to the faultline literature, which has not yet considered this characteristic. Lastly, we investigate the 
effect of formal board evaluation on the relationship between faultlines and board role performance, which also contributes to practice, as board evaluation may represent a solution to bridge potential negative faultline effects.

\section{Literature review and hypotheses}

\subsection{Board role performance: Definition and level of analysis}

Board role performance represents the degree to which boards successfully fulfill their control and service role (Forbes \& Milliken, 1999; van den Heuvel, Van Gils, \& Voordeckers, 2006; Westphal, 1999). The control role is important in family firms. As family owners' wealth is often concentrated in one firm, they have a strong incentive to closely monitor top executives (Bammens et al., 2011). Indeed, even in case the top management team is composed of solely family members, research by Schulze, Lubatkin, and Dino (2003) and Lubatkin, Schulze, Ling, and Dino (2005) has shown the interests of family members need not be perfectly aligned. Moreover, there might also be stakeholders (e.g., minority shareholders) whose interests might differ from those of the controlling family, and who would depend on the board of directors for oversight on certain decisions and behaviours of the controlling family (Bammens et al., 2011; Zattoni et al., 2015). Board control tasks entail, for example: selecting new managers, determining the management's salary or directing succession problems (van den Heuvel et al., 2006).

The service role is relevant as well, as board members bring important additional resources to the firm (Hillman \& Dalziel, 2003; Pfeffer \& Salancik, 1978; Zahra \& Pearce Ii, 1989) that could remedy potential shortcomings of the family managers (van den Heuvel et al., 2006). Indeed, as family members often possess more specific firm-related knowledge than general business knowledge (Bammens et al., 2011), a board composed of members that possess 
valuable and complementary points of view may provide additional expertise to the family management. Board service tasks entail, for example: building organizational reputation, networking or advising management (van den Heuvel et al., 2006)

\subsection{Faultlines and board role performance}

Various studies have investigated the impact of faultlines on group performance (e.g., Bezrukova et al., 2009; Homan et al., 2008; Thatcher et al., 2003). The majority of these studies show a negative effect of these "hypothetical dividing lines" on group-level outcomes (Thatcher \& Patel, 2011, 2012), suggesting the presence of faultlines to be an important explanatory variable for group functioning (Lau \& Murnighan, 1998). While an extensive body of research discusses the positive effects of diversity on group performance (Bell, Villado, Lukasik, Belau, \& Briggs, 2011; Jehn, Northcraft, \& Neale, 1999), the presence of faultlines might nullify this positive influence. Faultlines split a group's members based on the alignment of several diversity attributes (Lau \& Murnighan, 1998) and this may have potential detrimental effects on team functioning, for instance, owing to increased relationship conflict (Choi \& Sy, 2010; Lim, Busenitz, \& Chidambaram, 2013).

Strategic-decision making teams like new venture teams, top management teams and boards of directors can suffer from strong faultline settings. Barkema and Shvyrkov (2007), for instance, found that strong faultline settings hamper communication within TMTs, while communication is crucial to making complex decisions involving strategic innovation. With regard to the context of board of directors, Kaczmarek, Kimino, and Pye (2012), for example, concluded that board task-related faultlines have a strong negative effect on financial performance. These task-related faultlines are based on task-related attributes such as functional background, education or tenure, which might create a knowledge barrier between the board 
members (Kaczmarek et al., 2012). Despite of this research, contributions regarding the faultline effect in the context of boards still remain limited.

In line with previous research, we use social identity and social categorization theories to explain faultlines (Ashforth \& Mael, 1989; Brewer \& Kramer, 1985; Hogg \& Terry, 2000; Meyer et al., 2014; Tajfel \& Turner, 2004). According to these theories, group members perceive each other as being part of different social categories, causing subgroups to form when some members share a common identity, values and social characteristics. This may lead to members of one subgroup feeling little personal attachment to members of another subgroup (i.e., the out-group) and therefore favouring interaction with their own subgroup members (i.e., the in-group) (Carton \& Cummings, 2012; Kunze \& Bruch, 2010). Individuals, by nature, desire to feel included, and strive for a positive social identity (Brewer \& Kramer, 1985; Tajfel \& Turner, 2004). When more attributes of members align, members likely identify themselves more with their respective subgroups rather than with the group as a whole (Bezrukova, Thatcher, \& Jehn, 2007). The result of these faultlines and subgroups may be decreased cohesiveness of the group (Lau \& Murnighan, 1998), reduced trust (Polzer, Crisp, Jarvenpaa, \& Kim, 2006), lesser decision-quality (Rico et al., 2007) or lower productive energy (Kunze \& Bruch, 2010), which may finally result in lower board role performance (Forbes \& Milliken, 1999).

Applying these theories to family firms, we can see the apparent divide between members of the family and others, as family members are believed to form a highly committed in-group (Uhlaner et al., 2007). Family members are often involved in the firm since its foundation, feel part of the organization, and value that membership more than nonfamily members (Deephouse \& Jaskiewicz, 2013). They grow up with the firm, frequently hearing stories about it. The company is often an essential part of their personal life and identity 
(Murphy \& Lambrechts, 2015). Because of this strong identification with the company (Dyer \& Whetten, 2006; Zellweger, Eddleston, \& Kellermanns, 2010), family members possess unique social and human capital (Sirmon \& Hitt, 2003), might pursue family-centred goals (Carney, 2005), and may seek to preserve socioemotional wealth, that is, the "non-financial aspects of the firm that meet the family's affective needs" (Gómez-Mejía, Haynes, NúñezNickel, Jacobson, \& Moyano-Fuentes, 2007, p. 107). They share a common culture, values and identity (Sundaramurthy \& Kreiner, 2008), and are more emotionally invested in the firm than nonfamily members (Astrachan \& Jaskiewicz, 2008). Furthermore, Tagiuri and Davis (1996) state that family members share a common history, know each other's strengths and weaknesses, may have strong emotional bonds, and even share a "family language". Moreover, family members see each other more often, which leads to more communication and increased awareness of each other's circumstances (Tagiuri \& Davis, 1996).

Taken together, we argue that when the family board members identify strongly with the firm and the family (Zellweger et al., 2010), strong family membership-related faultlines may occur, which may lead to an identity-based subgroup (Carton \& Cummings, 2012). The formation of this subgroup could consequently result in a lower cohesiveness of the board, which is an important determinant of board effectiveness (Forbes \& Milliken, 1999).

Board members in the family can thus split on the basis of the family membership attribute, but they can also divide on the basis of the type of directorship (i.e., executive, nonexecutive or other). This may lead to the respective subgroups and in turn result in the performance losses that we previously discussed. Indeed, Basco and Voordeckers (2015) noticed the potential divide on the basis of type of directorship and state that, in order to decrease the risk of subgroup formation, the outsider ratio should be less than 50 per cent, as to avoid two subgroups with comparable power. Executive directors often have more access to 
internal resources and have more interactions with other executive directors, which may heighten the identification of these members with the own subgroup. On the other hand, nonexecutive directors often share the same external networks, and may possess their own, different kind of knowledge and capabilities (Bezemer, Maassen, Van den Bosch, \& Volberda, 2007).

Additionally, members of the board in a family firm may divide on the basis of their gender. The gender of group members is an easily observable attribute and members will therefore quickly classify each other in the respective categories (i.e., male or female) (Tajfel \& Turner, 2004). In family firms, women are increasingly rising to leadership and ownership positions (Cole, 1997; Jimenez, 2009; Nelton, 1998). However, women in family business encounter several obstacles due to traditional perspectives on the role that women have in the business. For instance, women in family firms face problems with invisibility or not being viewed in the same way as men (Cole, 1997; Jimenez, 2009), the "glass ceiling" (Songini \& Gnan, 2009) and the role that primogeniture still plays in family business succession (Vera \& Dean, 2005). According to the primogeniture criterion, it is self-evident that the firstborn male child should take over the family firm (Jimenez, 2009). This specific gender stereotyping could also exist in the boardroom, which may lead to male versus female subgroupings. When there is alignment of these three attributes (i.e., family membership, type of directorship and gender) for some board members, faultlines are expected to be strong. For example, a board that contains two female family executive directors and two male nonfamily nonexecutive directors may have two homogeneous subgroups. In this case, faultlines are strong as there is high member similarity within the subgroups and low member similarity between the subgroups (Shaw, 2004). 
To summarize, different attributes may be present in a family board of directors, all of which may be a strong base for a faultline and should thus be considered simultaneously when calculating faultline strength, in line with Lau and Murnighan's (1998) conceptualization of faultlines. Therefore, on the basis of these arguments, we posit that faultlines will be present in family firm boards, based on the alignment of the attributes "family membership", "type of directorship", and "gender", and will be negatively associated with board role performance, measured in this study as the degree to which boards successfully fulfill their control and service role:

Hypothesis 1: Faultlines, based simultaneously on family-membership, type of directorship and gender, will be negatively related to board role performance.

\subsection{Faultlines and board role performance: the moderating role of board evaluation}

Prior studies have argued that the effects of faultlines depend on contextual conditions (Meyer et al., 2014) and this may be the case for boards of directors in family firms as well. For example, Kaczmarek et al. (2012) found that in busy boards (i.e., boards in which many directors hold multiple board seats) and in boards on which long-tenured CEOs have a seat, the negative effect of faultlines was exacerbated while this negative effect was less pronounced in firms where executive directors' pay was related to firm performance.

In our study, we focus on formal board evaluation as a contextual variable. Board evaluations can be linked to value creation for boards (Rasmussen, 2015) and may enhance leadership, role clarity, teamwork, accountability, decision making, communication and operations in a board (Kiel \& Nicholson, 2005). Moreover, evaluations may help boards in handling performance pressures and preventing potential governance failures (Kiel \& 
Nicholson, 2005). In addition, board evaluations can potentially bring to attention the board members' responsibility towards the stakeholders of the company (Kiel \& Nicholson, 2005).

We argue that an evaluation will inform the board members about the current situation and future goals, which are important prerequisites for effective team learning (Decuyper, Dochy, \& Van den Bossche, 2010), which in turn is a crucial component of team effectiveness (Edmondson et al., 2007). Moreover, board reflexivity, defined as "the extent to which group members overtly reflect upon, and communicate about the group's objectives, strategies and processes, and adapt them to current or anticipated circumstances" (West, Garrod, \& Carletta, 1997, p. 296), is likely to transpire during evaluations or debriefings, and is essential for effective team learning as well (Decuyper et al., 2010).

Furthermore, board evaluations provide an opportunity for board members to address several topics that are important for team functioning. According to Fry, Rubin, and Plovnick (1981), groups that want to increase their effectiveness, should develop shared meaning about what the team tries to achieve ("goals"), who is going to do what to achieve these goals ("roles"), how people wish to work together in performing their roles ("procedures"), and how they wish to relate and communicate in order to achieve the necessary collaboration (“interpersonal relations”) (Bouwen \& Fry, 1996; Fry et al., 1981). This conversational process may shift the attention away from the subgroups to the board as a whole, leading to a higher level of group cohesiveness (Lau \& Murnighan, 1998).

Moreover, board evaluations may contribute to the formation of a collective team identity (Bezrukova et al., 2009; Edmondson et al., 2007; Homan et al., 2008; Van Der Vegt \& Bunderson, 2005), through discussing organizational goals (Nederveen Pieterse, Van Knippenberg, \& Van Dierendonck, 2013) and shared objectives (van Knippenberg, Dawson, West, \& Homan, 2011). Indeed, Bezrukova et al. (2009) found that when members identify 
themselves with the team rather than with a particular subgroup, a team was more able to reap the benefits of the team's diversity. Consequently, evaluating the board could ameliorate the negative effects of faultlines on team functioning. Therefore, we expect that the implementation of formal board evaluation will positively influence the relationship between faultlines and board role performance. Therefore, we posit:

Hypothesis 2: The negative relationship between faultlines and board role performance will be positively moderated by the presence of formal board evaluation.

\section{Methods}

\subsection{Research setting and data collection}

We derived unique empirical data from a wider data collection effort held in the period 20022003 on different variables characterizing a sample of Belgian private family firms (e.g., variables related to strategy, environment, board composition, management, succession, performance $)^{1}$.

For the purpose of the study, a family business was classified as such if: (1) at least 50 per cent of the shares are family-owned and management is controlled by the family, or (2) at least 50 per cent of the shares are family-owned and the company is not managed by a family CEO but the CEO perceives the firm as a family firm. This is in line with commonly used definitions of family firms (Chrisman, Chua, \& Sharma, 2005; Chua, Chrisman, \& Sharma, 1999; Westhead \& Howorth, 2006).

\footnotetext{
${ }^{1}$ Belgian companies operate under the one-tier board system, which means that both executive and nonexecutive directors form one board. In the period after this data collection, specific but non-compulsory guidelines were developed in order to guide non-listed (family) firms in establishing good governance.
} 
Using the financial database Belfirst, supplied by Bureau Van Dijk, a sample of 3,400 potential privately-owned family firms was collected and a survey was sent to the CEO. After sending a reminder to all the potential respondents, 311 responses were received ( 9.2 per cent). To check for non-response bias, we contacted a random sample of non-respondents to request data about certain firm characteristics. None of these variables showed significant differences when comparing the data of non-respondents to respondents in our sample. After excluding the firms not matching the definition criteria, 295 family firms remained.

When board members do not meet regularly, and therefore have less face-to-face interactions, the concept of board dynamics becomes less relevant (Pugliese, Nicholson, \& Bezemer, 2015). Therefore, in our final sample, we only include family firms that possessed active boards, that is boards with at least two formal meetings a year. Furthermore, we only include boards that have at least three members, as these boards are consistent with the definition of a team (i.e., composed of three or more individuals) (Hackman, 1987; Hoegl \& Gemuenden, 2001). This resulted in a final dataset of 126 firms.

After data screening, in which we deleted unusable entries due to missing values with regard to our main variables, the final dataset consisted of 106 valid cases for our dependent variable control role performance, and 102 firms for our dependent variable service role performance. The sample of 106 boards represented a total of 479 directors, while the sample of 102 boards represented a total of 451 directors. Table 1 provides an overview of the relative distribution of the respondents in terms of their firm and board characteristics.

\footnotetext{
**** Insert Table 1 about here $* * * *$
} 


\subsection{Measures}

\subsubsection{Dependent variable}

The dependent variables in this study were based on multiple-item constructs, measured through a five point Likert-type scale. We measured board role performance as the degree to which boards successfully fulfill their control and service role.

Control role performance was measured through six items. CEOs were asked to rate the degree to which the board (i) selects new managers, (ii) determines management's responsibility, (iii) determines salary/compensation of management, (iv) directs succession problems, (v) maximises shareholder value, (vi) evaluates/controls management performance (van den Heuvel et al., 2006). Factor analysis showed that all items load on one factor. We calculated the mean of these items to compute the control role performance and the Cronbach's alpha equals 0.830, indicating a high level of internal consistency (Hair, Black, Babin, Anderson, \& Tatham, 2006).

Service role performance was measured through five items where the CEO rated to what extent the board fulfilled the following tasks: (i) building organizational reputation, (ii) networking and maintaining relations, (iii) advising management, (iv) formulating/ratifying organizational strategy, (v) taking care of access to extra resources (van den Heuvel et al., 2006). Factor analysis confirmed the unidimensionality of this scale. The variable service role performance was calculated as a mean of those five items, and also showed a high level of internal consistency, as the Cronbach's alpha equals 0.735 (Hair et al., 2006). 


\subsubsection{Independent variable}

The independent variable in our analyses was the faultline strength (FLS), employing the formula developed by Shaw $(2004)^{2}$. In this study, the statistical software language R was used to run Meyer and Glenz's (2013) program, which was specifically designed to calculate group faultlines. Shaw's measure assesses the extent to which categorical attributes are aligned within subgroups and deviate between subgroups. This method provided us with a thorough analysis of substructures within a team, and a detailed view on relations between in-groups and outgroups (Meyer \& Glenz, 2013).

Calculating FLS using Shaw's method involved several steps. First, different attributes had to be identified. To calculate FLS, we used three attributes: family membership, type of directorship, and gender. A board member could either be "part of the family" or "not part of the family". Type of directorship was divided into four categories: "executive director", "affiliated director", "outside director with company shares" and "outside director without company shares" and a board member would belong to one category. Finally, a board member was categorized as "female" or "male". Secondly, since Shaw's faultline measure is not suitable for numeric data, all attributes had to be categorical. This was already the case for our study, so categorization was not required. Next, the program measured the subgroup internal alignment (IA). IA denotes "the extent to which members within a particular subgroup are similar to one another on all other relevant attributes" (Shaw, 2004, p. 72) and can range in value from 0.0 to 1.0 with 0.0 indicating no alignment and 1.0 indicating total alignment within a subgroup. The fourth step was computing the cross-subgroup alignment (CGAI), which refers to the extent

\footnotetext{
${ }^{2}$ We followed the recommendations made by Meyer et al. (2014) for choosing the most appropriate faultline measure given our research setting.
} 
that group members of different subgroups formed by one attribute share the same category of all other attributes. This value ranges from 0.0 to 1.0 as well. Lastly, the faultline measure FLS was calculated as follows: FLS = IA x (1 - CGAI) so each FLS score will also range between 0.0 and 1.0, and increases with faultline strength. For example, a board that is composed of four male family executive members is extremely homogeneous and would therefore have a faultline strength equal to 0 . However, in a board composed of four members with an alignment of two attributes for two members (e.g., they are both family and male, but one is an executive director and the other is a nonexecutive), and an alignment of two attributes for the other two members (e.g., they are both nonfamily and female, but one is an executive director and the other is a nonexecutive), faultlines would be stronger (as indicated by Shaw, 2004). The Meyer and Glenz's (2013) program provided us with a faultline strength for each board of directors.

As we calculated faultline strength based on objective data resulting from the questionnaire, used different response formats for the different variables (Podsakoff, MacKenzie, Jeong-Yeon, \& Podsakoff, 2003), and are studying interaction effects (Siemsen, Roth, \& Oliveira, 2010), common method bias concerns are substantially mitigated.

\subsubsection{Moderating variable}

In order to examine the moderating impact of board evaluation on the relationship between FLS and board role performance, we constructed a dummy, coded "1" if there was a formal board evaluation and "0" otherwise. This variable was derived from the survey.

\subsubsection{Control variables}

In our analysis, we used three control variables to capture firm or board level effects that could affect the relationships under study. At firm level, we controlled for firm size measured as the number of employees. Firm size has been an important factor in board research, as for instance 
boards of larger firms can be expected to engage more in strategic decisions (Fiegener, 2005). This variable was derived from the financial database Belfirst, provided by Bureau Van Dijk. At board level, we controlled for board size, indicated by the number of board members. This variable was included as it can be expected that larger boards will be more able to provide additional resources (Corbetta \& Salvato, 2004; Forbes \& Milliken, 1999). In addition, we controlled for independent director ratio. Previous research has pointed out that the board's independence may be for instance positively related to their monitoring effectiveness (Corbetta $\&$ Salvato, 2004). This variable was measured as the total number of independent directors, divided by the total board size. These last two variables were derived from the questionnaire.

\section{Analysis and results}

In this study, we applied a hierarchical regression model to test our hypotheses. In the extended models which included the moderating variable, the independent variable highly correlated with the interaction term. Therefore, these variables were mean-centred (Aiken \& West, 1991; Cohen, Cohen, West, \& Aiken, 2003). We computed variance inflation factors (VIF) to assess whether there was a multicollinearity problem in our sample. Since all values were lower than 4.95 , there was no problem of multicollinearity in our analyses (Kennedy, 2008). To test for heteroscedasticity, we performed a White's general test and a Cook-Weisberg test. Both indicated there were no problems concerning heteroscedasticity. Table 2 provides means, standard deviations, and correlations of variables. On average, firms have 63 employees. Furthermore, the independent director ratio is relatively low (10\%) and the average board size is 4.50 members, which is comparable to other studies conducted in the context of family firm boards (Basco \& Voordeckers, 2015; Collin \& Ahlberg, 2012; Zattoni et al., 2015). The average faultline strength included in our sample is 0.05 and the maximum faultline strength measured 
is 0.22 . According to Shaw (2004), these numbers indicate that the average faultline strength is rather weak, but that rather strong faultlines are also present in the upper quartile, showing a wide variance of faultline strengths in our sample ${ }^{3}$. Furthermore, our average faultline strength is comparable with other studies that calculate faultline strength using Shaw's method, as these average values range from 0.03 to 0.14 (e.g., Choi \& Sy, 2010; Meyer \& Glenz, 2013).

\section{$* * * *$ Insert Table 2 about here $* * * *$}

Table 3 shows the results of the regression analysis with board control role performance as the dependent variable and Table 4 the results with service role performance as the dependent variable. For each dependent variable, we analysed five models to examine our hypotheses and also verify whether including additional variables increased the variance explained. Moreover, following these steps, we can test for moderation (Hayes, 2013). The first model (model 1) includes only the control variables. From the results presented in this model, we learn that firm size yields significant results regarding board control performance, but not for board service performance. Subsequently, FLS was introduced and tested (model 2). Finally, we added the moderating variable and the interaction term (model 3). Although the reported $\mathrm{R}^{2} \mathrm{~s}$ are relatively low, the changes in $\mathrm{R}^{2}$ were significant when adding the faultline strength as a predictor in the second model. The results show that hypothesis 1 was supported. For our dependent variable control role performance, the variable FLS in model 3 was significant at the $1 \%$ level. For service role performance, the variable was significant at the $5 \%$ level. Second, we tested whether formal board evaluation moderates the relationship between faultlines and board role

\footnotetext{
${ }^{3}$ Shaw (2004) does not specify the exact threshold values that should be used to categorize groups into different faultline levels, but would consider a faultline strength of 0.16 as rather strong (p. 68).
} 
performance (model 3). For control role performance, we indeed found that formal board evaluation had a moderating effect. The interaction term was significant at the $5 \%$ level. The negative effect of faultlines seemed to be counteracted by the presence of formal board evaluation (see Figure 1). The negative effect was reversed in this case. However, for service role performance, we did not find any significant results for the sample of 102 firms (Figure 2), hence hypothesis 2 was only partly supported. As the control variables did not add to the explanatory power of the models predicting service role performance, we also tested our hypotheses without them (model 4 and 5). In these additional tests, our main results remained significant and the significance of the model improved substantially.

Subsequently, we executed a set of robustness tests. We made the observation that some boards in our sample were relatively homogeneous and therefore had no or only weak faultlines. However, in the case of family firms, this homogeneity represents a real-life occurrence, as most family firm boards still only contain family, executive directors. Therefore, to measure the effect of moderate to strong faultlines and to make sure the significant effect was not only due to these homogeneous groups, we repeated the analysis without the boards with no or weak faultlines. The results of this additional test remained similar to our primary findings concerning the faultline effect, as the variable FLS was significant at the 5\% level for our dependent variable control role performance. For service role performance, the variable was significant at the $10 \%$ level. With regard to the dependent variable control role performance, the interaction term was significant at the $10 \%$ level. Unlike our mean analysis, this test revealed a significant coefficient for our interaction term, regarding the dependent variable board service role performance (at the $10 \%$ level). Additionally, while skewness did not pose a problem in our study, we repeated the analysis with the logarithmic transformation of the FLS score, as suggested by Shaw (2004). This additional test revealed similar results. 
**** Insert Table 3 and 4 about here $* * * *$

**** Insert Figure 1 and 2 about here $* * * *$

\section{Discussion and conclusion}

\subsection{Theoretical and practical contributions}

While the relationship between board demographics and firm performance has received a great deal of attention from researchers, insights into the actual behaviour of boards have only recently begun to emerge. By investigating the board role performance in family firms, while adopting principles from the literature on group dynamics and effectiveness, this study reflects the impact of group dynamics on board role performance and responds to calls in the corporate governance literature to open up the "black box" of corporate boards (Huse et al., 2011). Our study provides new insights regarding the influence of faultlines on board control and service role performance respectively (Forbes \& Milliken, 1999). While diversity has been argued beneficial for performance, we find that the presence of faultlines can be an important downside of greater diversity in the boardroom of family firms. We provide evidence that the presence of faultlines, based on three attributes (family membership, type of directorship, and gender), negatively influences both board control and board service role performance. We thereby show the role faultlines play in the undermining of board effectiveness, through their influence on the board's cohesiveness (Lau \& Murnighan, 1998) or decision quality (Rico et al., 2007).

This study has several important implications for the literature. To start with, our study advances prior studies which addressed the effect of faultlines on firm performance instead of board role performance, focused only on faultline formation based on task-related attributes 
(e.g., Kaczmarek et al., 2012), and were limited to one faultline attribute (e.g., Basco \& Voordeckers, 2015; Minichilli et al., 2010). Our findings suggest that faultlines in family firms can be formed on the basis of more than one attribute, as we measure faultlines in line with the conceptualisation by Lau and Murnighan (1998), which is based on the alignment of several diversity attributes of individuals. Furthermore, this study extends the faultline literature, by adding the variable "family membership" as an additional social identity attribute. As the observed detrimental effect of faultlines was partly based on family membership, our findings confirm that there is a higher risk of identity-based subgroups in family firms. Our study further contributes to prior studies in the management literature linking the presence of faultines to organizational outcome variables such as firm performance (van Knippenberg et al., 2011), foreign expansion of firms (Barkema \& Shvyrkov, 2007), or teams' productive energy (Kunze \& Bruch, 2010). We go beyond these previous findings by providing evidence of the detrimental effect of faultlines in a board context; an important topic of which our knowledge was still rather limited.

Furthermore, we hypothesized and empirically found that these detrimental effects of faultlines are reversed by the presence of formal board evaluation. Our results indicate that formal board evaluation provides a solution to faultline problems, as certain processes come into play that mitigate faultline issues. When the board discusses the problems arising from these faultlines openly, there is room for potential positive effects of board diversity. Regarding this moderating role of formal board evaluation on the relationship between faultlines and board role performance, our study contributes to prior studies that indicated the importance of incorporating contextual conditions when studying faultlines in group contexts (e.g., Meyer et al., 2014). Indeed, the ameliorating effect of formal board evaluation occurred in the 
relationship between faultlines and board control role performance. However, with regard to board service role performance, there was no significant effect.

A potential explanation for this finding can be found in the amount of problems that arise from faultlines regarding each board role. Family members value the service role more than the control role (van den Heuvel et al., 2006), as they value the different perspectives outside directors bring to the board (Bammens et al., 2011). They desire that outside members assist in networking and maintaining relations or advise the management in determining the organizational strategy (van den Heuvel et al., 2006). However, when outside members are invited to join the board, mainly for their contribution to service tasks, they are legally obligated to perform control tasks as well (Bammens, Voordeckers, \& Van Gils, 2008). Confronted with this reality, the family may be afraid of losing a certain degree of control, which they need to preserve their socioemotional wealth interests (Gómez-Mejía et al., 2007). The members of the particular subgroups, when protecting their own interests, will identify more with the own subgroup instead of with the board as a whole. Therefore, when decisions involving the control role have to be made, there is an increased risk of intergroup conflicts arising from faultlines. Consequently, during the evaluation of the board, board members may focus more on problems regarding the control role than on issues involving the service role, which is why control role performance can benefit significantly more from formal board evaluation.

A second reason lies in the way the board is being evaluated. The board can be evaluated as a whole or the directors can be assessed individually (Rasmussen, 2015). Minichilli, Gabrielsson, and Huse (2007) recommend the use of peer evaluation, instead of individual director evaluation, since this may result in higher trust and openness among board members, which improves the decision-making culture in the boardroom. However, Kiel and Nicholson (2005) state that a well-designed evaluation covers both board-as-a-whole and individual 
director evaluation, while taking into account the specific purpose and objectives of the evaluation. For example, when boards wish to compare their performance over the years, using quantitative evaluation techniques are more suitable than qualitative evaluation methods (Kiel \& Nicholson, 2005). The specific purpose and objectives might have been different for control or service role decisions, and different types of evaluation might have been used.

Overall, our findings reflect a group dynamics and effectiveness perspective on board role performance, while underscoring the role of conditional factors. Furthermore, these results have important implications for practice, as we propose formal board evaluation as a possible solution to bridge potential faultline issues in family firm boards.

While our study shows interesting results that indicate that the presence of faultlines influences board role performance, the rather low $\mathrm{R}^{2} \mathrm{~s}$ of our econometric models suggest that board role performance will be explained by a much wider array of factors. By focusing on faultlines, we have touched on only one aspect involved in understanding board role performance. We propose that team processes such as team learning behaviour (Edmondson, 1999; Gibson \& Vermeulen, 2003; Van Der Vegt \& Bunderson, 2005), board cohesiveness (Bettinelli, 2011; Forbes \& Milliken, 1999), group morale (Thatcher et al., 2003) and team motivation (Mitchell, Parker, \& Giles, 2011; Park, Spitzmuller, \& DeShon, 2013) may have significant additional explanatory power for board role performance. In addition, although the presence of faultlines may explain variance in board role performance as we show in our study, we believe that it is critical to examine destructive group patterns such as relationship conflict (Choi \& Sy, 2010; Jehn et al., 1999), behavioural disintegration (Li \& Hambrick, 2005), group polarization (Merchant \& Pick, 2010; Zhu, 2013) or pluralistic ignorance (Merchant \& Pick, 2010; Westphal \& Bednar, 2005). As family involvement in the business may have a strong effect on board internal processes (Zattoni et al., 2015), it is especially relevant to study these 
group patterns in a family firm context. These variables could all be introduced in order to explain more of the variance in board role performance, and future studies might use research designs that allow for incorporating these processes.

\subsection{Future research directions and limitations}

This study has limitations that point to future research opportunities. First, although inviting CEOs to answer our questionnaires has many advantages, such as the detailed knowledge they possess on what goes on in the boardroom ${ }^{4}$, incorporating views of other board members on board role performance can be useful in order to better understand and measure the board's role performance. Moreover, such a multi-perspectivistic approach would allow for a more detailed understanding about how the different types of board members assess and frame their board's performance.

Second, since our results are based on cross-sectional data, we are not able to draw inferences about the effects of faultlines over time. We agree with Srikanth, Harvey, and Peterson (2016) that the effects of diversity might unfold over time. Longitudinal data can provide additional insights in how the effects of faultlines might change over time, or what type of events might strengthen the influence of faultlines. Particularly within the context of family firms, it would be interesting to investigate what kind of events can trigger certain social identity conflicts (Chrobot-Mason, Ruderman, Weber, \& Ernst, 2009). For example, the effect of faultlines might be aggravated by extreme favouritism towards the family members (e.g., appointing of a family member irrespective of competencies) or overly strong cohesive family bonds in the board (e.g., the family acting as a "club" within the board).

\footnotetext{
${ }^{4}$ In Belgium, CEOs generally attend all board meetings, even when they are not a formal board member.
} 
In addition, our study only considers formal board evaluation as an important contextual variable moderating the relationship between faultlines and board performance in family firms, while several other moderators could be considered. Other contextual conditions that are promising to inquire into are for example, boards characterized by high team psychological safety (Edmondson, 1999), a transformational leader (Kunze \& Bruch, 2010), or shared leadership (Vandewaerde, Voordeckers, Lambrechts, \& Bammens, 2011). Transformational or shared leadership behaviours in the board might contribute to the creation of a collective team identity, as these leaders develop shared vision in the board (Kunze \& Bruch, 2010) and focus on shared organizational goals (Vandewaerde et al., 2011), thereby mitigating the effect of faultlines. Moreover, Roberge and van Dick (2010) state that members of heterogeneous groups need a psychological safe environment in addition to a collective team identity before they might engage in certain positive psychological processes that lead to increased group performance.

Finally, while conducting this study, several "micro-process" questions emerged during discussions in our research team and with colleague-scholars. How do faultlines actually develop over time, what are underlying mechanisms, and when do faultlines become problematic for group performance? How do social categorisation processes exactly work? How are faultlines experienced, framed, enacted and (constructively) handled by different actors that form a collective-in our case board members in family firms? These questions point to the need of developing and refining faultline theory itself. Indeed, although Lau and Murnighan (1998) started initial theorizing with regard to when faultlines may be the strongest and most likely, there is no clear framework yet of the conditions and boundaries that are needed to bound the application of the faultline concept (Smith \& Hitt, 2005). Such a framework is needed to understand how and why faultlines influence group performance. More specifically, 
the development of faultline theory would benefit from research that explores the spatial and temporal boundaries of the concept of faultlines (Bacharach, 1989). Furthermore, since Lau and Murnighan (1998) introduced faultlines as a new variable in demographic diversity research, the dominant approach used in faultline studies has been empirical, with a focus on how to measure group faultlines. Therefore, we argue that there is a need for much more theory development that addresses our previous questions and stresses the importance of underlying micro-processes (Sutton \& Staw, 1995). We agree with Meyer et al. (2014) and Srikanth et al. (2016) that theory on faultlines can be advanced by adopting a more micro-level approach of faultlines-in-(inter)action. Qualitative, interpretative case study research (e.g., Fletcher, De Massis, \& Nordqvist, 2016; Murphy \& Lambrechts, 2015) that aims to elaborate and develop theory concerning faultline process questions seems therefore called for. Literature that links the quality of relating or handling differences (e.g., in terms of power, perspectives, interests, expertise) between a diversity of actors to the quality of teaming and organizing might contribute greatly in this respect (e.g., Dewulf \& Bouwen, 2012; Lambrechts, Grieten, Bouwen, \& Corthouts, 2009). Especially, how a group values and handles differences in power (Lambrechts, Taillieu, Grieten, \& Poisquet, 2012) or status (Maloney, Bresman, ZellmerBruhn, \& Beaver, 2016) is an interesting research question. Moreover, as underlying group processes might be time-sensitive (Srikanth et al., 2016), future research may use a more dynamic perspective and include time as an important variable in models that explain the complex phenomenon of faultlines in group settings. 


\section{REFERENCES}

Aiken, L. S., \& West, S. G. (1991). Multiple regression: Testing and interpreting interactions. Thousand Oakes, CA: Sage Publications.

Anderson, R. C., \& Reeb, D. M. (2004). Board Composition: Balancing Family Influence in S\&P 500 Firms. Administrative Science Quarterly, 49(2), 209-237.

Ashforth, B. E., \& Mael, F. (1989). Social Identity Theory and the Organization. Academy of Management Review, 14(1), 20-39.

Astrachan, J. H., \& Jaskiewicz, P. (2008). Emotional Returns and Emotional Costs in Privately Held Family Businesses: Advancing Traditional Business Valuation. Family Business Review, 21(2), 139-149.

Bacharach, S. B. (1989). Organizational theories: Some criteria for evaluation. Academy of Management Review, 14(4), 496-515.

Bammens, Y., Voordeckers, W., \& Van Gils, A. (2008). Boards of directors in family firms: a generational perspective. Small Business Economics, 31(2), 163-180.

Bammens, Y., Voordeckers, W., \& Van Gils, A. (2011). Boards of Directors in Family Businesses: A Literature Review and Research Agenda. International Journal of Management Reviews, 13(2), 134-152.

Barkema, H. G., \& Shvyrkov, O. (2007). Does Top Management Team Diversity Promote or Hamper Foreign Expansion? Strategic Management Journal, 28(7), 663-680.

Basco, R., \& Voordeckers, W. (2015). The relationship between the board of directors and firm performance in private family firms: A test of the demographic versus behavioral approach. Journal of Management \& Organization, 21(4), 1-25.

Bell, S. T., Villado, A. J., Lukasik, M. A., Belau, L., \& Briggs, A. L. (2011). Getting Specific about Demographic Diversity Variable and Team Performance Relationships: A MetaAnalysis. Journal of Management, 37(3), 709-743.

Bettinelli, C. (2011). Boards of Directors in Family Firms: An Exploratory Study of Structure and Group Process. Family Business Review, 24(2), 151-169.

Bezemer, P.-J., Maassen, G. F., Van den Bosch, F. A. J., \& Volberda, H. W. (2007). Investigating the Development of the Internal and External Service Tasks of Nonexecutive Directors: the case of the Netherlands (1997-2005). Corporate Governance: An International Review, 15(6), 1119-1129. 
Bezrukova, K., Jehn, K., Zanutto, E., \& Thatcher, S. (2009). Do Workgroup Faultlines Help or Hurt? A Moderated Model of Faultlines, Team Identification, and Group Performance. Organization Science, 20(1), 35-50.

Bezrukova, K., Thatcher, S. M., \& Jehn, K. A. (2007). Group heterogeneity and faultlines: Comparing alignment and dispersion theories of group composition. In K. J. Behfar \& L. L. Thompson (Eds.), Conflict in organizational groups: New directions in theory and practice (pp. 57-92). Evanston, IL: The Northwestern University Press.

Bezrukova, K., \& Uparna, J. (2009). Group splits and culture shifts: A new map of the creativity terrain. In M.A.Neale, B.Mannix, \& J.Goncalo (Eds.), Research on Managing Groups and Teams (Vol. 12, pp. 161-191). Stamford, CT: JAI Press.

Bouwen, R., \& Fry, R. (1996). Facilitating group development: Interventions for a relational and contextual construction. In M. A. West (Ed.), Handbook of work group psychology (pp. 531-552). London: John Wiley \& Sons Ltd.

Brewer, M. B., \& Kramer, R. M. (1985). The Psychology of Intergroup Attitudes and Behavior. Annual Review of Psychology, 36(1), 219.

Carney, M. (2005). Corporate Governance and Competitive Advantage in Family-Controlled Firms. Entrepreneurship: Theory \& Practice, 29(3), 249-265.

Carton, A. M., \& Cummings, J. N. (2012). A Theory of Subgroups in Work Teams. Academy of Management Review, 37(3), 441-470.

Choi, J. N., \& Sy, T. (2010). Group-level organizational citizenship behavior: Effects of demographic faultlines and conflict in small work groups. Journal of Organizational behavior, 31(7), 1032-1054.

Chrisman, J. J., Chua, J. H., \& Sharma, P. (2005). Trends and Directions in the Development of a Strategic Management Theory of the Family Firm. Entrepreneurship: Theory \& Practice, 29(5), 555-575.

Chrobot-Mason, D., Ruderman, M. N., Weber, T. J., \& Ernst, C. (2009). The challenge of leading on unstable ground: Triggers that activate social identity faultlines. Human Relations, 62(11), 1763-1794.

Chua, J. H., Chrisman, J. J., \& Sharma, P. (1999). Defining the Family Business by Behavior. Entrepreneurship: Theory \& Practice, 23(4), 19-39. 
Cohen, J., Cohen, P., West, S. G., \& Aiken, L. S. (2003). Applied multiple regression/correlation analysis for the behavioral sciences. Mahwah, JN: Lawrence Erlbaum Associates.

Cole, P. M. (1997). Women in family business. Family Business Review, 10(4), 353-371.

Collin, S. Y., \& Ahlberg, J. (2012). Blood in the boardroom: Family relationships influencing the functions of the board. Journal of Family Business Strategy, 3, 207-219.

Corbetta, G., \& Salvato, C. A. (2004). The Board of Directors in Family Firms: One Size Fits All? Family Business Review, 17(2), 119-134.

Daily, C. M., Dalton, D. R., \& Cannella Jr, A. A. (2003). Corporate Governance: Decades of Dialogue and Data. Academy of Management Review, 28(3), 371-382.

Dalton, D. R., Daily, C. M., Ellstrand, A. E., \& Johnson, J. L. (1998). Meta-analytic reviews of board composition, leadership structure, and financial performance. Strategic Management Journal, 19(3), 269-290.

Decuyper, S., Dochy, F., \& Van den Bossche, P. (2010). Grasping the dynamic complexity of team learning: An integrative model for effective team learning in organisations. Educational Research Review, 5(2), 111-133.

Deephouse, D. L., \& Jaskiewicz, P. (2013). Do Family Firms Have Better Reputations Than Non-Family Firms? An Integration of Socioemotional Wealth and Social Identity Theories. Journal of Management Studies, 50(3), 337-360.

Dewulf, A., \& Bouwen, R. (2012). Issue Framing in Conversations for Change: Discursive Interaction Strategies for "Doing Differences". The Journal of applied behavioral science, 48(2), 168-193.

Dyer, W. G., \& Whetten, D. A. (2006). Family Firms and Social Responsibility: Preliminary Evidence from the S\&P 500. Entrepreneurship: Theory \& Practice, 30(6), 785-802.

Edmondson, A. (1999). Psychological Safety and Learning Behavior in Work Teams. Administrative Science Quarterly, 44(2), 350-383.

Edmondson, A., Dillon, J., \& Roloff, K. (2007). Three Perspectives on Team Learning Outcome Improvement, Task Mastery, and Group Process. Academy of Management Annals, 1(1), 269-314.

Fiegener, M. K. (2005). Determinants of Board Participation in the Strategic Decisions of Small Corporations. Entrepreneurship: Theory \& Practice, 29(5), 627-650. 
Fletcher, D., De Massis, A., \& Nordqvist, M. (2016). Qualitative research practices and family business scholarship: A review and future research agenda. Journal of Family Business Strategy, 7(1), 8-25.

Forbes, D. P., \& Milliken, F. J. (1999). Cognition and Corporate Governance: Understanding Boards of Directors as Strategic Decision-making Groups. Academy of Management Review, 24(3), 489-505.

Fry, R., Rubin, I., \& Plovnick, M. (1981). Dynamics of groups that execute or manage policy. In R. Payne \& C. Cooper (Eds.), Groups at work. (pp. 41-57). New York: John Wiley \& Sons.

Gabrielsson, J., \& Huse, M. (2005). Outside directors in SME boards: a call for theoretical reflections. Corporate Board: role, duties and composition, 1(1), 28-37.

Gibson, C., \& Vermeulen, F. (2003). A Healthy Divide: Subgroups as a Stimulus for Team Learning Behavior. Administrative Science Quarterly, 48(2), 202-239.

Gómez-Mejía, L. R., Haynes, K. T., Núñez-Nickel, M., Jacobson, K. J. L., \& MoyanoFuentes, J. (2007). Socioemotional Wealth and Business Risks in Family-controlled Firms: Evidence from Spanish Olive Oil Mills. Administrative Science Quarterly, 52(1), 106-137.

Hackman, J. R. (1987). The design of work teams. In J. Lorsch (Ed.), Handbook of Organizational Behavior (pp. 315-342). Englewood Cliffs, NJ: Prentice-Hall.

Hair, J. F., Black, W. C., Babin, B. J., Anderson, R. E., \& Tatham, R. L. (2006). Multivariate data analysis (Vol. 6): Pearson Prentice Hall Upper Saddle River, NJ.

Hayes, A. F. (2013). Introduction to mediation, moderation, and conditional process analysis: A regression-based approach: Guilford Press.

Hillman, A. J., \& Dalziel, T. (2003). Boards of Directors and Firm Performance: Integrating Agency and Resource Dependence Perspectives. Academy of Management Review, 28(3), 383-396.

Hoegl, M., \& Gemuenden, H. G. (2001). Teamwork Quality and the Success of Innovative Projects: A Theoretical Concept and Empirical Evidence. Organization Science, 12(4), 435-449.

Hogg, M. A., \& Terry, D. J. (2000). Social Identity and Self-Categorization Processes in Organizational Contexts. Academy of Management Review, 25(1), 121-140. 
Homan, A. C., Hollenbeck, J. R., Humphrey, S. E., Van Knippenberg, D., Ilgen, D. R., \& Van Kleef, G. A. (2008). Facing Differences With An Open Mind: Openness to Experience, Salience of Intragroup Differences, and Performance of Diverse Work Groups. Academy of Management Journal, 51(6), 1204-1222.

Huse, M., Hoskisson, R., Zattoni, A., \& Viganò, R. (2011). New perspectives on board research: changing the research agenda. Journal of Management \& Governance, $15(1), 5-28$.

Jehn, K. A., Northcraft, G. B., \& Neale, M. A. (1999). Why Differences Make a Difference: A Field Study of Diversity, Conflict, and Performance in Workgroups. Administrative Science Quarterly, 44(4), 741-763.

Jimenez, R. M. (2009). Research on Women in Family Firms: Current Status and Future Directions. Family Business Review, 22(1), 4-4.

Johnson, J. L., Ellstrand, A. E., \& Daily, C. M. (1996). Boards of Directors: A Review and Research Agenda. Journal of Management, 22(3), 409-438.

Kaczmarek, S., Kimino, S., \& Pye, A. (2012). Board Task-related Faultlines and Firm Performance: A Decade of Evidence. Corporate Governance: An International Review, 20(4), 337-351.

Kennedy, P. (2008). A guide to econometrics (6th ed.). Cambridge, MA: Wiley-Blackwell. Kiel, G. C., \& Nicholson, G. J. (2005). Evaluating Boards and Directors. Corporate Governance: An International Review, 13(5), 613-631.

Kunze, F., \& Bruch, H. (2010). Age-Based Faultlines and Perceived Productive Energy: The Moderation of Transformational Leadership. Small Group Research, 41(5), 593-620.

Lambrechts, F., Grieten, S., Bouwen, R., \& Corthouts, F. (2009). Process Consultation Revisited Taking a Relational Practice Perspective. The Journal of applied behavioral science, 45(1), 39-58.

Lambrechts, F., Taillieu, T., Grieten, S., \& Poisquet, J. (2012). In-depth joint supply chain learning: towards a framework. Supply Chain Management: An International Journal, 17(6), 627-637.

Lau, D. C., \& Murnighan, J. K. (1998). Demographic Diversity and Faultlines: the Compositional Dynamics of Organizational Groups. Academy of Management Review, 23(2), 325-340. 
Li, J., \& Hambrick, D. C. (2005). Factional Groups: A New Vantage on Demographic Faultlines, Conflict, and Disintegration in Work Teams. Academy of Management Journal, 48(5), 794-813.

Lim, J. Y., Busenitz, L. W., \& Chidambaram, L. (2013). New Venture Teams and the Quality of Business Opportunities Identified: Faultlines Between Subgroups of Founders and Investors. Entrepreneurship: Theory \& Practice, 37(1), 47-67.

Lubatkin, M. H., Schulze, W. S., Ling, Y., \& Dino, R. N. (2005). The effects of parental altruism on the governance of family-managed firms. Journal of Organizational behavior, 26(3), 313-330.

Maloney, M. M., Bresman, H., Zellmer-Bruhn, M. E., \& Beaver, G. R. (2016). Contextualization and Context Theorizing in Teams Research: A Look Back and a Path Forward. The Academy of Management Annals, 1-52.

Merchant, K. A., \& Pick, K. (2010). Blind Spots, Biases, and Other Pathologies in the Boardroom. New York: Business Expert Press.

Meyer, B., \& Glenz, A. (2013). Team Faultline Measures: A Computational Comparison and a New Approach to Multiple Subgroups. Organizational Research Methods, 16(3), 393-424.

Meyer, B., Glenz, A., Antino, M., Rico, R., \& González-Romá, V. (2014). Faultlines and Subgroups: A Meta-Review and Measurement Guide. Small Group Research, 45(6), 633-670.

Minichilli, A., Corbetta, G., \& MacMillan, I. C. (2010). Top Management Teams in FamilyControlled Companies: 'Familiness', 'Faultlines', and Their Impact on Financial Performance. Journal of Management Studies, 47(2), 205-222.

Minichilli, A., Gabrielsson, J., \& Huse, M. (2007). Board Evaluations: making a fit between the purpose and the system. Corporate Governance: An International Review, 15(4), 609-622.

Mitchell, R. J., Parker, V., \& Giles, M. (2011). When do interprofessional teams succeed? Investigating the moderating roles of team and professional identity in interprofessional effectiveness. Human Relations, 64(10), 1321-1343.

Murphy, L., \& Lambrechts, F. (2015). Investigating the actual career decisions of the next generation: The impact of family business involvement. Journal of Family Business Strategy, 6(1), 33-44. 
Nederveen Pieterse, A., Van Knippenberg, D., \& Van Dierendonck, D. (2013). Cultural Diversity and Team Performance: The Role of Team Member Goal Orientation. Academy of Management Journal, 56(3), 782-804.

Nelton, S. (1998). The rise of women in family firms: A call for research now. Family Business Review, 11(3), 215-218.

Park, G., Spitzmuller, M., \& DeShon, R. P. (2013). Advancing Our Understanding of Team Motivation: Integrating Conceptual Approaches and Content Areas. Journal of Management, 39(5), 1339-1379.

Pettigrew, A. M. (1992). On studying managerial elites. Strategic Management Journal, 13(S2), 163-182.

Pfeffer, J., \& Salancik, G. R. (1978). The External Control of Organizations: A Resource Dependence Perspective. New York: Harper \& Row.

Podsakoff, P. M., MacKenzie, S. B., Jeong-Yeon, L., \& Podsakoff, N. P. (2003). Common Method Biases in Behavioral Research: A Critical Review of the Literature and Recommended Remedies. Journal of Applied Psychology, 88(5), 879.

Polzer, J. T., Crisp, C. B., Jarvenpaa, S. L., \& Kim, J. W. (2006). Extending the faultline model to geographically dispersed teams: How colocated subgroups can impair group functioning. Academy of Management Journal, 49(4), 679-692.

Pugliese, A., Nicholson, G., \& Bezemer, P. (2015). An Observational Analysis of the Impact of Board Dynamics and Directors' Participation on Perceived Board Effectiveness. British Journal of Management, 26(1), 1-25.

Rasmussen, J. (2015). Do Board Evaluations Measure Board Effectiveness? International Studies of Management \& Organization, 45(1), 80-98.

Rico, R., Molleman, E., Sanchez-Manzanares, M., \& Vegt, G. S. V. d. (2007). The Effects of Diversity Faultlines and Team Task Autonomy on Decision Quality and Social Integration. Journal of Management, 33(1), 111-132.

Roberge, M.-É., \& van Dick, R. (2010). Recognizing the benefits of diversity: When and how does diversity increase group performance? Human Resource Management Review, 20(4), 295-308.

Schulze, W. S., Lubatkin, M. H., \& Dino, R. N. (2003). Exploring the Agency Consequences of Ownership Dispersion Among the Directors of Private Family Firms. Academy of Management Journal, 46(2), 179-194. 
Shaw, J. B. (2004). The Development and Analysis of a Measure of Group Faultlines. Organizational Research Methods, 7(1), 66-100.

Siemsen, E., Roth, A., \& Oliveira, P. (2010). Common Method Bias in Regression Models With Linear, Quadratic, and Interaction Effects. Organizational Research Methods, 13(3), 456-476.

Sirmon, D. G., \& Hitt, M. A. (2003). Managing Resources: Linking Unique Resources, Management, and Wealth Creation in Family Firms. Entrepreneurship: Theory \& Practice, 27(4), 339-358.

Smith, K. G., \& Hitt, M. A. (2005). Great minds in management: The process of theory development: Oxford University Press on Demand.

Songini, L., \& Gnan, L. (2009). Women, Glass Ceiling, and Professionalization in Family SMEs: A Missed Link. Journal of Enterprising Culture, 17(4), 497-525.

Srikanth, K., Harvey, S., \& Peterson, R. (2016). A Dynamic Perspective on Diverse Teams: Moving from the Dual-Process Model to a Dynamic Coordination-based Model of Diverse Team Performance. The Academy of Management Annals, 10(1), 453-493.

Sundaramurthy, C., \& Kreiner, G. E. (2008). Governing by Managing Identity Boundaries: The Case of Family Businesses. Entrepreneurship: Theory \& Practice, 32(3), 415436.

Sutton, R. I., \& Staw, B. M. (1995). What theory is not. Administrative Science Quarterly, 371-384.

Tagiuri, R., \& Davis, J. (1996). Bivalent attributes of the family firm. Family Business Review, 9(2), 199-208.

Tajfel, H., \& Turner, J. C. (2004). The Social Identity Theory of Intergroup Behavior. In S. Worchel \& W. G. Austin (Eds.), The Psychology of Intergroup Relations (pp. 7-24). Chicago: Nelson-Hall.

Thatcher, S., Jehn, K., \& Zanutto, E. (2003). Cracks in Diversity Research: The Effects of Diversity Faultlines on Conflict and Performance. Group Decision \& Negotiation, $12(3), 217-241$.

Thatcher, S., \& Patel, P. (2011). Demographic Faultlines: A Meta-Analysis of the Literature. Journal of Applied Psychology, 96(6), 1119-1139.

Thatcher, S., \& Patel, P. (2012). Group Faultlines: A Review, Integration, and Guide to Future Research. Journal of Management, 38(4), 969-1009. 
Uhlaner, L., Wright, M., \& Huse, M. (2007). Private Firms and Corporate Governance: An Integrated Economic and Management Perspective. Small Business Economics, 29(3), 225-241.

van den Heuvel, J., Van Gils, A., \& Voordeckers, W. (2006). Board Roles in Small and Medium-Sized Family Businesses: performance and importance. Corporate Governance: An International Review, 14(5), 467-485.

Van Der Vegt, G. S., \& Bunderson, J. S. (2005). Learning and Performance in Multidisciplinary Teams: The Importance of Collective Team Identification. Academy of Management Journal, 48(3), 532-547.

van Ees, H., Gabrielsson, J., \& Huse, M. (2009). Toward a Behavioral Theory of Boards and Corporate Governance. Corporate Governance: An International Review, 17(3), 307319.

van Knippenberg, D., Dawson, J. F., West, M. A., \& Homan, A. C. (2011). Diversity faultlines, shared objectives, and top management team performance. Human Relations, 64(3), 307-336.

Vandewaerde, M., Voordeckers, W., Lambrechts, F., \& Bammens, Y. (2011). Board Team Leadership Revisited: A Conceptual Model of Shared Leadership in the Boardroom. Journal of Business Ethics, 104(3), 403-420.

Vera, C. F., \& Dean, M. A. (2005). An Examination of the Challenges Daughters Face in Family Business Succession. Family Business Review, 18(4), 321-345.

West, M. A., Garrod, S., \& Carletta, J. (1997). Group decision-making and effectiveness: Unexplored boundaries. In C. L. Cooper \& S. E. Jackson (Eds.), Creating tomorrow's organizations (pp. 293-317). Chichester: Wiley.

Westhead, P., \& Howorth, C. (2006). Ownership and Management Issues Associated With Family Firm Performance and Company Objectives. Family Business Review, 19(4), 301-316.

Westphal, J. D. (1999). Collaboration in the boardroom: Behavioral and performance consequences of CEO-board social ties. Academy of Management Journal, 42(1), 724.

Westphal, J. D., \& Bednar, M. K. (2005). Pluralistic ignorance in corporate boards and firms' strategic persistence in response to low firm performance. Administrative Science Quarterly, 50(2), 262-298. 
Westphal, J. D., \& Zajac, E. J. (2013). A Behavioral Theory of Corporate Governance: Explicating the Mechanisms of Socially Situated and Socially Constituted Agency. The Academy of Management Annals, 7(1), 607-661.

Zahra, S. A., \& Pearce Ii, J. A. (1989). Boards of Directors and Corporate Financial Performance: A Review and Integrative Model. Journal of Management, 15(2), 291. Zattoni, A., Gnan, L., \& Huse, M. (2015). Does Family Involvement Influence Firm Performance? Exploring the Mediating Effects of Board Processes and Tasks. Journal of Management, 41(4), 1214-1243.

Zellweger, T. M., Eddleston, K. A., \& Kellermanns, F. W. (2010). Exploring the concept of familiness: Introducing family firm identity. Journal of Family Business Strategy, 1(1), 54-63.

Zhu, D. H. (2013). Group polarization on corporate boards: Theory and evidence on board decisions about acquisition premiums. Strategic Management Journal, 34(7), 800-822.

Zona, F. (2015). Board ownership and processes in family firms. Small Business Economics, 44(1), 105-122. 


\section{TABLES AND FIGURES}

Table 1. Distribution of respondents

\begin{tabular}{|c|c|c|c|c|}
\hline & \multicolumn{2}{|c|}{ Control role } & \multicolumn{2}{|c|}{ Service Role } \\
\hline & $N$ & $\%$ & $N$ & $\%$ \\
\hline \multicolumn{5}{|l|}{ Firm characteristics } \\
\hline \multicolumn{5}{|l|}{ Number of employees } \\
\hline $0-50$ & 71 & 67 & 67 & 65.7 \\
\hline $50-250$ & 26 & 24.5 & 26 & 25.5 \\
\hline$>250$ & 9 & 8.5 & 9 & 8.8 \\
\hline \multicolumn{5}{|l|}{ Life-cycle stage } \\
\hline Growth stage & 36 & 34.0 & 36 & 35.3 \\
\hline Maturity stage & 57 & 53.8 & 52 & 51.0 \\
\hline Consolidation stage & 10 & 9.4 & 12 & 11.8 \\
\hline Missing & 3 & 2.8 & 2 & 2.0 \\
\hline \multicolumn{5}{|l|}{ Industry } \\
\hline Manufacturing & 44 & 41.5 & 40 & 39.2 \\
\hline Construction & 11 & 10.4 & 11 & 10.8 \\
\hline Wholesale & 23 & 21.7 & 23 & 22.5 \\
\hline Retail & 13 & 12.3 & 13 & 12.7 \\
\hline Services & 15 & 14.2 & 15 & 14.7 \\
\hline \multicolumn{5}{|l|}{ Type of CEO } \\
\hline Entrepreneur of first generation & 27 & 25.5 & 27 & 26.5 \\
\hline Family successor (i.e., second or later generation) & 72 & 67.9 & 68 & 66.7 \\
\hline Nonfamily CEO & 7 & 6.6 & 7 & 6.9 \\
\hline \multicolumn{5}{|l|}{ Board characteristics } \\
\hline \multicolumn{5}{|l|}{ Board size } \\
\hline $3-5$ & 83 & 78.3 & 78 & 76.5 \\
\hline $6-8$ & 19 & 17.9 & 19 & 18.6 \\
\hline $9-12$ & 4 & 3.8 & 5 & 4.9 \\
\hline \multicolumn{5}{|l|}{ Gender } \\
\hline Male & 372 & 77.6 & 347 & 76.9 \\
\hline Female & 107 & 22.3 & 104 & 23.1 \\
\hline \multicolumn{5}{|l|}{ Number of formal board meetings } \\
\hline $2-4$ & 68 & 64.2 & 63 & 61.8 \\
\hline $5-8$ & 19 & 17.9 & 20 & 19.6 \\
\hline$>9$ & 19 & 17.9 & 19 & 18.6 \\
\hline
\end{tabular}


Table 2. Descriptive statistics and correlation matrix

\begin{tabular}{lcccccccc}
\hline \hline & Mean & SD & 1 & 2 & 3 & 4 & 5 & 6 \\
\hline \hline 1. Control Role & 2.92 & 0.86 & & & & & & \\
2. Service Role & 3.40 & 0.80 & $0.60^{* *}$ & & & & & \\
3. Board Size & 4.50 & 2.05 & -0.06 & -0.08 & & & & \\
4. Firm Size & 63.62 & 94.16 & $0.21^{*}$ & -0.03 & $0.48^{* *}$ & & & \\
5. Independent & 0.10 & 0.18 & -0.05 & -0.14 & $0.32^{* *}$ & $0.30^{* *}$ & & \\
Director Ratio & & & & & & & & \\
6. Formal Board & 0.14 & 0.35 & -0.06 & 0.082 & -0.02 & -0.14 & 0.03 & \\
Evaluation & 0.05 & 0.06 & $-0.23^{*}$ & $-0.22^{*}$ & $0.32^{* *}$ & $0.20^{*}$ & 0.13 & 0.07 \\
7. Faultlines & 0 & & & & & & \\
\hline \hline * $<0.1 ; * \mathrm{p}<0.05, * * * \mathrm{p}<0.01$
\end{tabular}


Table 3. Results of hierarchical regression analyses: control role performance

\begin{tabular}{|c|c|c|c|c|c|}
\hline Regressors & Model 1 & Model 2 & Model 3 & Model 4 & Model 5 \\
\hline Firm size & $\begin{array}{l}0.00 * * * \\
(0.00)\end{array}$ & $\begin{array}{l}0.00 * * * \\
(0.00)\end{array}$ & $\begin{array}{l}0.00 * * * \\
(0.00)\end{array}$ & & \\
\hline Board size & $\begin{array}{l}-0.08^{*} \\
(0.05)\end{array}$ & $\begin{array}{l}-0.04 \\
(0.05)\end{array}$ & $\begin{array}{l}-0.06 \\
(0.05)\end{array}$ & & \\
\hline $\begin{array}{l}\text { Independent } \\
\text { director ratio }\end{array}$ & $\begin{array}{l}-0.37 \\
(0.47)\end{array}$ & $\begin{array}{l}-0.37 \\
(0.46)\end{array}$ & $\begin{array}{l}-0.36 \\
(0.45)\end{array}$ & & \\
\hline Faultlines & & $\begin{array}{l}-3.85 * * * \\
(1.56)\end{array}$ & $\begin{array}{l}-3.92 * * * \\
(1.54)\end{array}$ & $\begin{array}{l}-3.54^{* *} \\
(1.49)\end{array}$ & $\begin{array}{l}-3.58 * * \\
(1.48)\end{array}$ \\
\hline Formal Board Evaluation & & & $\begin{array}{l}-0.05 \\
(0.22)\end{array}$ & & $\begin{array}{l}-0.16 \\
(0.22)\end{array}$ \\
\hline $\begin{array}{l}\text { Faultlines x Formal Board } \\
\text { Evaluation }\end{array}$ & & & $\begin{array}{l}9.50 * * \\
(4.00)\end{array}$ & & $\begin{array}{l}8.11 * \\
(4.13)\end{array}$ \\
\hline F-statistic & $3.10 * *$ & $3.96 * * *$ & $3.68 * * *$ & $5.64 * *$ & $3.26 * *$ \\
\hline $\mathrm{R}^{2}$ & 0.08 & 0.14 & 0.18 & 0.05 & 0.09 \\
\hline Adjusted $\mathrm{R}^{2}$ & 0.06 & 0.10 & 0.13 & 0.04 & 0.06 \\
\hline$\Delta \mathrm{R}^{2}$ & $0.08 * *$ & $0.05 * *$ & $0.05 *$ & $0.05 * *$ & 0.04 \\
\hline $\mathrm{N}$ & 106 & 106 & 106 & 106 & 106 \\
\hline
\end{tabular}


Table 4. Results of hierarchical regression analyses: service role performance

\begin{tabular}{|c|c|c|c|c|c|}
\hline Regressors & Model 1 & Model 2 & Model 3 & Model 4 & Model 5 \\
\hline Firm size & $\begin{array}{l}0.00 \\
(0.00)\end{array}$ & $\begin{array}{l}0.00 \\
(0.00)\end{array}$ & $\begin{array}{l}0.00 \\
(0.00)\end{array}$ & & \\
\hline Board size & $\begin{array}{l}-0.02 \\
(0.04)\end{array}$ & $\begin{array}{l}-0.00 \\
(0.04)\end{array}$ & $\begin{array}{l}-0.01 \\
(0.04)\end{array}$ & & \\
\hline $\begin{array}{l}\text { Independent } \\
\text { director ratio }\end{array}$ & $\begin{array}{l}-0.6 \\
(0.46)\end{array}$ & $\begin{array}{l}-0.54 \\
(0.45)\end{array}$ & $\begin{array}{l}-0.56 \\
(0.45)\end{array}$ & & \\
\hline Faultlines & & $\begin{array}{l}-3.12 * * \\
(1.48)\end{array}$ & $\begin{array}{l}-3.34 * * \\
(1.60)\end{array}$ & $\begin{array}{l}-3.19 * * \\
(1.39)\end{array}$ & $\begin{array}{l}-3.33^{* *} \\
(1.40)\end{array}$ \\
\hline Formal Board Evaluation & & & $\begin{array}{l}0.21 \\
(0.23)\end{array}$ & & $\begin{array}{l}0.17 \\
(0.23)\end{array}$ \\
\hline $\begin{array}{l}\text { Faultlines x Formal Board } \\
\text { Evaluation }\end{array}$ & & & $\begin{array}{l}5.09 \\
(4.12)\end{array}$ & & $\begin{array}{l}4.98 \\
(4.06)\end{array}$ \\
\hline F-statistic & 0.73 & 1.68 & 1.64 & $5.25 * *$ & $2.65^{*}$ \\
\hline $\mathrm{R}^{2}$ & 0.02 & 0.07 & 0.09 & 0.05 & 0.08 \\
\hline Adjusted $\mathrm{R}^{2}$ & -0.01 & 0.03 & 0.04 & 0.04 & 0.05 \\
\hline$\Delta \mathrm{R}^{2}$ & 0.02 & $0.04 * *$ & 0.03 & $0.05^{* *}$ & 0.03 \\
\hline $\mathrm{N}$ & 102 & 102 & 102 & 102 & 102 \\
\hline
\end{tabular}




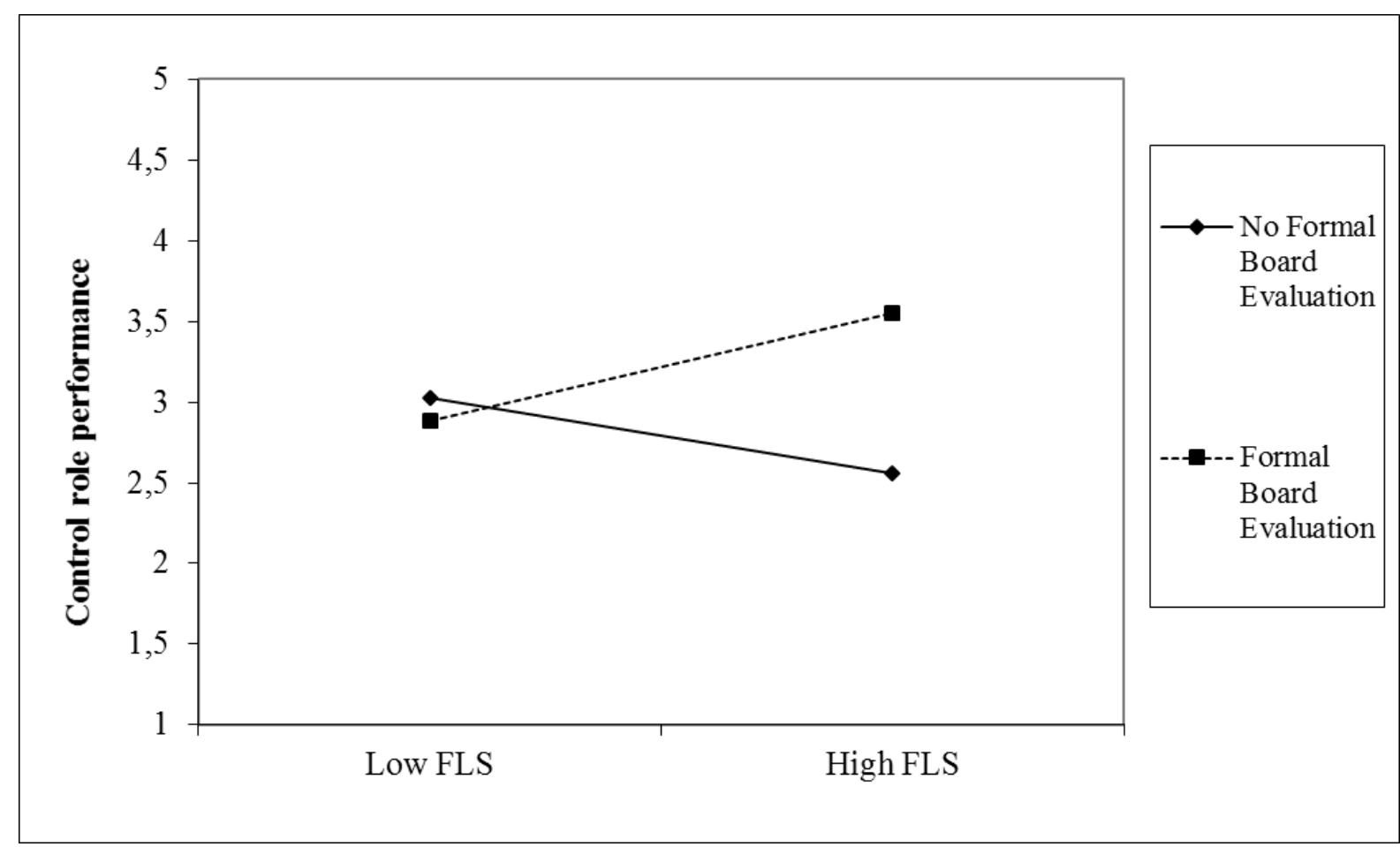

Figure 1. Effect of interaction between faultlines and formal board evaluation on board control role performance.

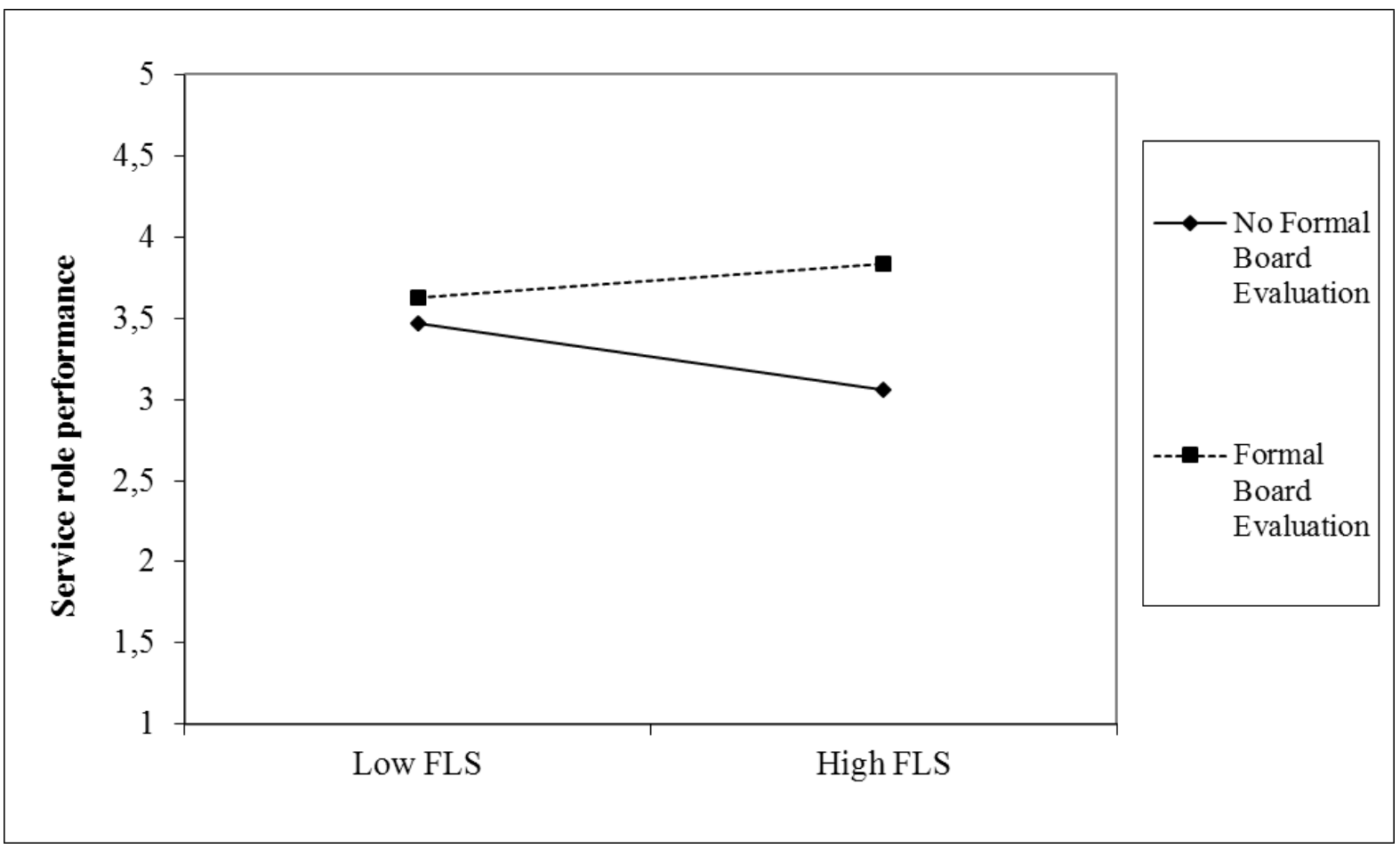

Figure 2. Effect of interaction between faultlines and formal board evaluation on board service role performance. 